\title{
Optimization of the current self-assembled urinary bladder model: Organ-specific stroma and smooth muscle inclusion
}

\author{
Hazem Orabi, MD; ${ }^{*{ }^{*} t}$ Alexandre Rousseau, MD; ${ }^{*}$ Veronique Laterreur, MD; ${ }^{*}$ Stephane Bolduc, MD, FRCSC ${ }^{*}$ \\ *Centre de recherche en organogénèse expérimentale de I'Université Laval/LOEX, Faculté de médecine, Université Laval, QC; §Surgery Department (Urology Service), Université Laval, QC; †Urology \\ Department, Assiut University, Egypt
}

Cite as: Can Urol Assoc J 2015;9(9-10):E599-607. http://dx.doi.org/10.5489/cuaj.2953 Published online September 9, 2015.

\section{Abstract}

Introduction: Due to the complications associated with the use of non-native biomaterials and the lack of local tissues, bioengineered tissues are required for surgical reconstruction of complex urinary tract diseases, including those of the urinary bladder. The selfassembly method of matrix formation using autologous stromal cells obviates the need for exogenous biomaterials. We aimed at creating novel ex-vivo multilayer urinary tissue from a single bladder biopsy.

Methods: After isolating urothelial, bladder stromal and smooth muscle cells from bladder biopsies, we produced 2 models of urinary equivalents: (1) the original one with dermal fibroblasts and (2) the new one with bladder stromal cells. Dermal fibroblasts and bladder stromal cells were stimulated to form an extracellular matrix, followed by sequential seeding of smooth muscle cells and urothelial cells. Stratification and cellular differentiation were assessed by histology, immunostaining and electron microscopy. Barrier function was checked with the permeability test. Biomechanical properties were assessed with uniaxinal tensile strength, elastic modulus, and failure strain.

Results: Both urinary equivalents could be handled easily and did not contract. Stratified epithelium, intact basement membrane, fused matrix, and prominent muscle layer were detected in both urinary equivalents. Bladder stromal cell-based constructs had terminally differentiated urothelium and more elasticity than dermal fibroblasts-based equivalents. Permeation studies showed that both equivalents were comparable to native tissues.

Conclusions: Organ-specific stromal cells produced urinary tissues with more terminally differentiated urothelium and better biomechanical characteristics than non-specific stromal cells. Smooth muscle cells could be incorporated into the selfassembled tissues effectively. This multi-layer tissue can be used as a urethral graft or as a bladder model for disease modelling and pharmacotherapeutic testing.

\section{Introduction}

Studying the development and differentiation of the urothelium is important to understand many bladder pathologies, urothelium healing, and regenerative processes. Although there are many animal and ex vivo models to study the urinary bladder, none of them allow proper investigation of the normal development and differentiation of the human urothelium. Due to slow turnover of the umbrella cells, postinjury inflammation and hyperplasia, ethical drawbacks and animal cost, the in vivo study of urothelial differentiation and development is difficult. ${ }^{1-4}$ The investigation of preor postnatal differentiation in rodents does not follow the same pathways in human. ${ }^{5}$ In vitro studies can avoid these obstacles; however, these studies have limitations. The monolayer models lack the complex three-dimensional (3D) structure, the variety of cell types, and differentiation state present in $3 \mathrm{D}$ environment. Although tissue explants models have been created, ${ }^{6,7}$ they have certain deficiencies, including limited availability, insufficient viability of thawn tissues and potential transfer of infectious agents. The current $3 \mathrm{D}$ cell culture models $s^{8,9}$ lack the structural architecture of functional tissue and use only one cell type. Also, the use of exogenous matrices would alter the signaling pathways and the process of differentiation and leads to inflammatory response and fibrosis if grafted.

To avoid these problems, we have previously created an in vitro model of urinary bladder with dermal fibroblasts (DF) and urothelial cells (UCs). ${ }^{10-12}$ As smooth muscle cells (SMCs) are responsible for urine transport and evacuation, their inclusion in any tissue-engineered graft for urinary tract is required. ${ }^{13}$ Therefore, we aimed in this study to produce a more biomimetic urinary tissue that closely simulated urinary tissue by using organ-specific stromal cells to produce urinary ECM and incorporating SMCs. 


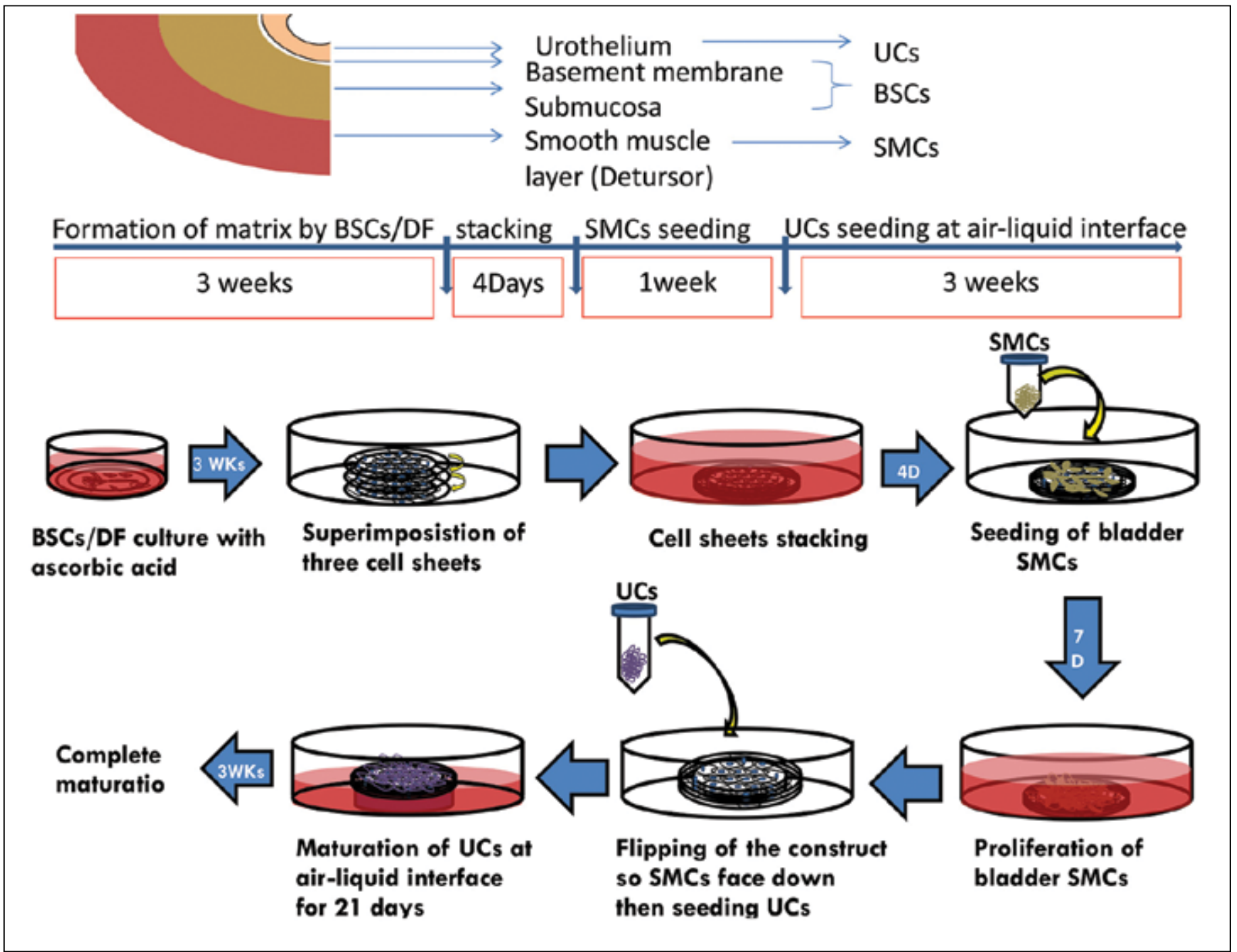

Fig. 1. The study plan. In the upper panel, each cell type is extracted from a different portion within the same single bladder biopsy where urothelial cells (UCs) were extracted from mucosa, bladder stroma cells (BSCs) mainly from submucosa and smooth muscles (SMCs) from detrusor muscle. The main steps of urinary equivalent formation with time scale for each step is shown in middle panel. Illustrations for the steps of equivalent production with self-assembly technique are seen in the lower panel.

\section{Methods}

The Ethical Research Committee of our research centre approved this study. Two different types of urinary equivalents were constructed and evaluated: one using dermal fibroblasts (originally published) and the other new model using bladder stromal cells (BSCs). In both models, UCs and SMCs were seeded.

\section{Cell isolation}

Bladder biopsies were cut into small pieces and incubated overnight at $4^{\circ} \mathrm{C}$ in solution containing $500 \mathrm{mg} / \mathrm{mL}$ thermolysin (Sigma). The urothelial layer was then gently scraped off the rest of the biopsy to isolate UCs with trypsinization. The remaining part of the biopsy included the bladder submucosa (white colour) and SMCs (pink colour). The submucosa was dissected away from the SMC layer with sharp scissors; they were separately processed to isolate BSCs and SMCs with collagenase $\mathrm{H}$ solution $(0.125 \mathrm{U} / \mathrm{mL}$; Boehringer Mannheim, Laval, QC) as previously described..$^{10,14}$ The medium used to grow and expand UCs was DHc (composed of DMEM-Ham [Dulbecco modified Eagle medium-Ham 12] containing $10 \%$ fetal bovine serum [FBS, Invitrogen], $5 \mathrm{mg} / \mathrm{mL}$ insulin [Sigma], $0.4 \mathrm{mg} / \mathrm{mL}$ hydrocortisone [Calbiochem, San Diego, CA], 10-10 M cholera toxin [ICN, St-Laurent, QC], 10 mg/ $\mathrm{mL}$ epidermal growth factor [Austral Biologicals, San Ramon, $\mathrm{CA}])$, and antibiotics $(100 \mathrm{U} / \mathrm{mL}$ penicillin and $25 \mathrm{mg} / \mathrm{mL}$ 
gentamicin [Sigma]). The culture medium used for culture of BSCs and SMCs was DMEM, containing 10\% FBS and antibiotics. The phenotype of the isolated cells was checked with phase contract microscopy and immunofluorescence (pancytokeratins [AE] 1/AE3 for UCs and smooth muscle actin [SMA] and calponin for BSCs and SMCs).

DF were isolated from human skin biopsies as previously described using $0.2 \mathrm{U} / \mathrm{mL}$ collagenase $\mathrm{H}$ and cultured in DMEM medium supplemented with $10 \%$ FBS and antibiotics. $^{15}$

\section{Construction of urinary equivalents}

DF and BSCs were seeded separately in 6 well-cultured plates using $\mathrm{DH}$ medium with $10 \% \mathrm{FBS}$, antibiotics, and $50 \mu \mathrm{g} / \mathrm{mL}$ ascorbate for 21 days to form a collagen sheet. Three stromal sheets were superimposed to form one sheet. SMCs were then seeded on top of stromal sheets for 7 days. The construct was flipped and UCs were seeded on the other stromal side using differentiating medium (DHc, and keratinocyte serum free medium with bovine pituitary extract and epidermal growth factor [Gibco/Life Technology, Ontario] using a ratio of $60 \%: 40 \%$ ) plus $50 \mu \mathrm{g} / \mathrm{mL}$ ascorbate for 21 days at the air-liquid interface (Fig. 1).

\section{Histological evaluation}

Samples were fixed in 3.7\% neutral buffered formaldehyde solution and embedded in paraffin. Histological sections $(5 \mu \mathrm{m})$ were cut and stained using Masson's trichrome (MT) and Hematoxylin and eosin (H\&E).

Samples were embedded in frozen tissue medium (OCT compound). The primary antibodies used are described in Table 1. Secondary antibodies were coupled with Alexa 594 or Alexa 488 fluorochrome. For controls, the primary antibody was omitted. The specimens were then examined with a Nikon eclipse E600 epifluorescence microscope (Nikon, Tokyo, Japan) and images were processed with AxioVs 40 V4.8.2.0 (Carl Zeiss Microlmaging $\mathrm{GmbH}$ ).

\section{Functional studies}

Tissue permeability was evaluated using Franz cells and radioactively labelled urea ${ }^{14} \mathrm{C}$ at multiple time points for a maximum of 8 hours, as previously described.10,16 Both urinary equivalents were compared to native bladders.

\section{Mechanical testing}

Using a mechanical tester tester (Tytron 250, MTS Systems Corporation, $\mathrm{MN}$ ), we measured the mechanical properties of both urinary equivalents by uniaxial tensile testing (UTS), elastic modulus, and failure strain. Sample thickness was
Table 1. Primary antibodies used in the study

\begin{tabular}{|c|c|c|c|}
\hline Component & Antibody & Dilution & Source \\
\hline \multirow[t]{8}{*}{ Epithelium } & $A E 1,3$ & $1: 400$ & $\begin{array}{c}\text { Chemicon, Cambridge, } \\
\text { MA, USA }\end{array}$ \\
\hline & CK20 & $1: 100$ & $\begin{array}{c}\text { Abcam Inc., Cambridge, } \\
\text { MA, USA }\end{array}$ \\
\hline & CK14 & $1: 100$ & $\begin{array}{c}\text { Sigma, St Louis, } \\
\text { MO,USA }\end{array}$ \\
\hline & K5 & $1: 200$ & $\begin{array}{c}\text { Abcam Inc., Cambridge, } \\
\text { MA, USA }\end{array}$ \\
\hline & Ki-67 & $1 / 500$ & $\begin{array}{c}\text { Abcam Inc., Cambridge, } \\
\text { MA, USA }\end{array}$ \\
\hline & UPIII & $1: 50$ & $\begin{array}{c}\text { Santa Cruz, Santa Cruz, } \\
\text { CA, USA }\end{array}$ \\
\hline & E-cadherin & $1: 100$ & $\begin{array}{c}\text { Abcam Inc., Cambridge, } \\
\text { MA, USA }\end{array}$ \\
\hline & Occludin & $1: 500$ & $\begin{array}{c}\text { Mybiosource, San } \\
\text { Diego, CA,USA }\end{array}$ \\
\hline \multirow[t]{2}{*}{$\begin{array}{l}\text { Basement } \\
\text { membrane }\end{array}$} & LamininV & $1: 500$ & $\begin{array}{c}\text { Chemicon, Cambridge, } \\
\text { MA, USA }\end{array}$ \\
\hline & Collagen IV & $1: 800$ & $\begin{array}{c}\text { Abcam Inc., Cambridge, } \\
\text { MA, USA }\end{array}$ \\
\hline \multirow[t]{4}{*}{ Matrix } & Collagen III & $1: 200$ & $\begin{array}{c}\text { Cederlane, Burlington, } \\
\text { ON, Canada }\end{array}$ \\
\hline & Fibronectin & $1: 100$ & $\begin{array}{c}\text { ATCC, Manassas, VA, } \\
\text { USA }\end{array}$ \\
\hline & Laminin & $1: 200$ & $\begin{array}{c}\text { Abcam Inc., Cambridge, } \\
\text { MA, USA }\end{array}$ \\
\hline & Elastin & $1: 400$ & $\begin{array}{c}\text { Santa Cruz, Santa Cruz, } \\
\text { CA, USA }\end{array}$ \\
\hline \multirow[t]{4}{*}{$\begin{array}{l}\text { Smooth } \\
\text { muscle cells }\end{array}$} & SMA & 1:1000 & $\begin{array}{c}\text { Chemicon, Cambridge, } \\
\text { MA, USA }\end{array}$ \\
\hline & Calponin & $1: 500$ & $\begin{array}{c}\text { Santa Cruz, Santa Cruz, } \\
\text { CA, USA }\end{array}$ \\
\hline & Smoothelin & $1: 500$ & $\begin{array}{l}\text { Affinity BioReagents, } \\
\text { 3-Flow, CO, USA }\end{array}$ \\
\hline & Desmin & $1: 500$ & $\begin{array}{c}\text { Abcam Inc., Cambridge, } \\
\text { MA, USA }\end{array}$ \\
\hline
\end{tabular}

measured on histological cuts using the Image J software $(\mathrm{NIH}$, Bethesda, MD). Data were analyzed using Minitab (Minitab, State College, PA). Statistical comparison of the mechanical properties of both urinary equivalents was done using Student's t-test. Results are presented as mean \pm standard error $(\mathrm{SE})$, with $p<0.05$ considered statistically significant.

\section{Electron microscopy}

Samples of BSCs-SMCs equivalents were fixed with 2.5\% glutaraldehyde in cacodylate buffer at $4{ }^{\circ} \mathrm{C}$, rinsed with cacodylate buffer and post-fixed in $1 \%$ osmium tetroxide. Biopsies were dehydrated, dried, and sprayed with gold to be viewed with a Jeol JSM-63060LV (Tokyo, Japan). 


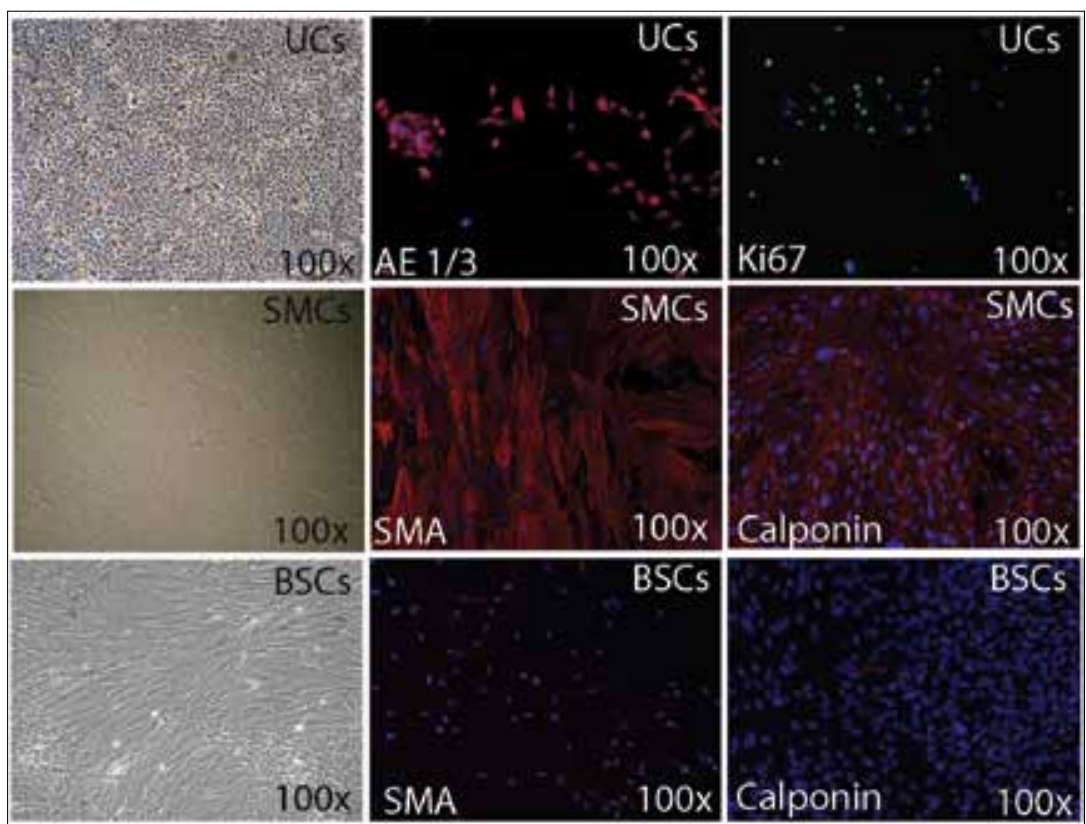

Fig. 2. Phenotype characterization of 3 cell types extracted from bladder biopsy with immunofluorescence. Urothelial cells (UCs) had the characteristic appearance under phase contrast microscopy and their phenotype with phase contrast microscopy, expressed epithelial markers (AE1/AE3) with immunofluorescence. Smooth muscle cells (SMCs) exhibited SMCs markers; smooth muscle actin and calponin. Bladder stromal cells (BSCs) manifested weak expression for SMA and no expression for calponin.

\section{Results}

\section{Cell isolation}

The 3 vesical cell types were successfully isolated and exhibited their characteristic phenotypes. Polygonal UCs expressed AE1/3 and KI-67 indicating high proliferative capacity. SMCs showed the typical spindle shape appearance with positive staining for SMCs markers. BSCs and DF showed different morphology with phase contrast microscopy, weak expression of SMA, and lack of expression for calponin (Fig. 2).

\section{Structure and architecture of urinary equivalent formation}

Both equivalents did not shrink and could be handled easily. On MT and H\&E, the sections demonstrated architecture similar to the urinary tract tissue composed of multilayer, well-stratified epithelium overlying a well-defined basement membrane, thick stroma, and a muscle layer (Fig. 3). The epithelial layer had normal cell polarization with the columnar cells forming the basal layer, the flat cells forming the superficial layer and rounded or polyhedral cells in-between. SMCs were aligned on the outer surface of the equivalent.

\section{Characterization of equivalents by immunoflourescence staining}

Both equivalents showed positive staining for the main ECM proteins: collagen I \&III, laminin, fibronectin and elastin, with greater expression of the last 3 for the BSCs equivalents (Fig. 3, part A). The expression of SMCs markers was evident with different distribution in both equivalents (Fig. 3, part B). Both equivalents presented UCs with positive staining to AE1/AE3. However, with regards to terminal differentiation, there was a remarkable difference in favour of the organ-specific BSCs equivalents, which showed minimal expression of CK14 and obvious expression of CK20, while DF-SMCs equivalents revealed remarkable expression of CK14, mainly in the basal cells with no expression of CK20. Both equivalents demonstrated positive staining for laminin $\mathrm{V}$ and collagen IV, matrix proteins of the basement membrane. Uroplakin III and E-cadherin were also detected (Fig. 4).

\section{Permeability function of the urinary equivalents}

Both the BSCs-based and DF-based equivalents revealed permeability comparable to native bladders, with no major difference after 8 hours (Fig. 5).

\section{Mechanical properties of urinary equivalents}

Delamination was observed in all DF-SMCs equivalents. DF-SMCs had significantly higher elastic modulus, while BCSs-SMCs had significantly higher stromal thickness. There was no significant difference between both urinary equivalents regarding failure strain and UTS (Fig. 6).

\section{Electron microscopy}

In 3D, electron microscopy defined the multilayered structure of BSCs-based equivalents. SMCs were clearly aligned. The cut section through the epithelium was wellstratified, with the most upper layer being flat, covered with urothelial plaques formed of uroplakins. Multiple microvillus cells were scattered among the UCs. Cell boundaries and tight junctions were identified (Fig. 7).

\section{Discussion}

Tissue engineering (TE) approaches include either the use of acellular matrices or the use of cell-seeded matrices. ${ }^{17}$ In the genitourinary field, most of the strategies for TE require cell-seeded matrices. ${ }^{18}$ Clinical trials have been initiated for 


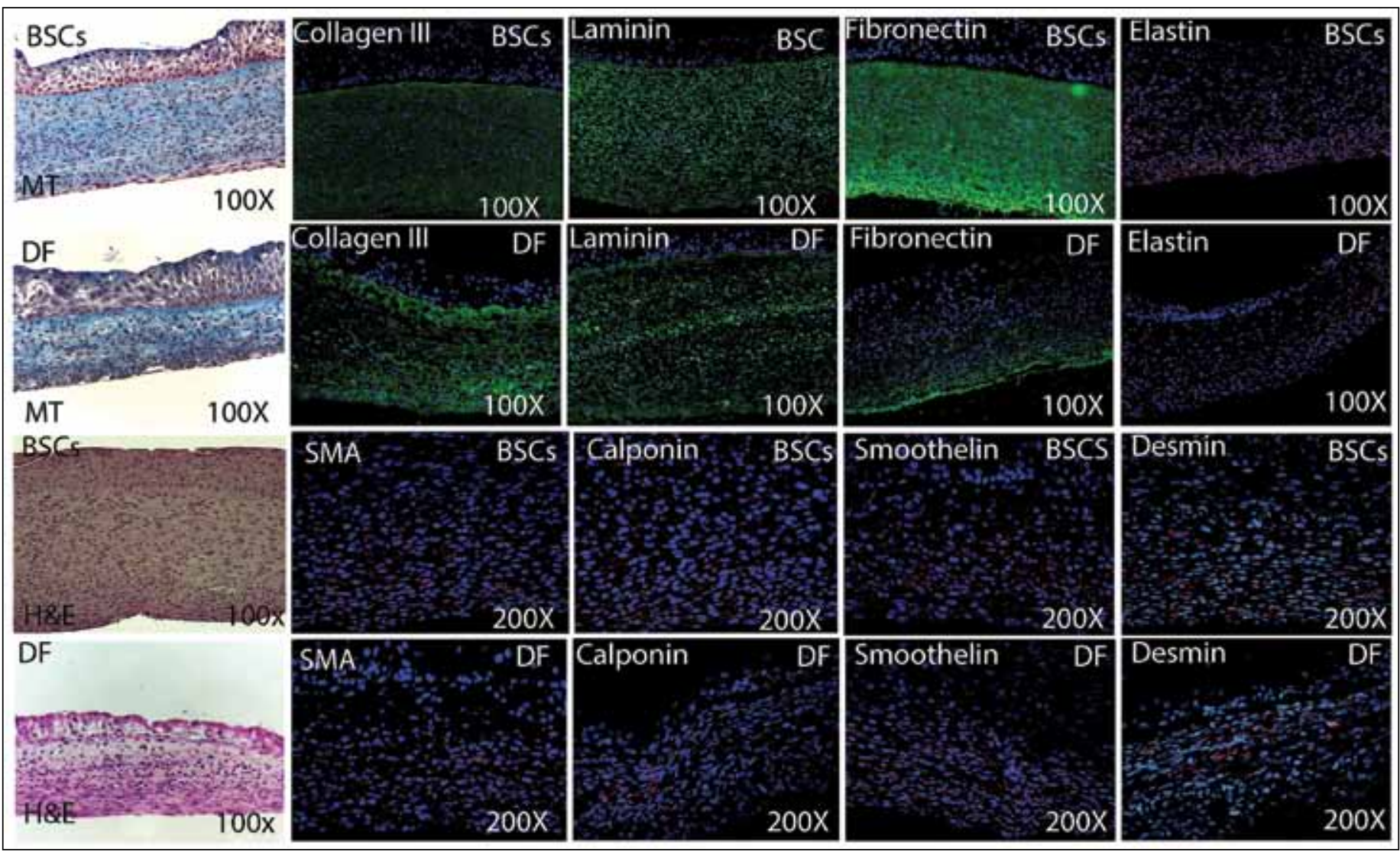

Fig. 3. Showing the tissue architecture with histochemical staining, different extracellular matrix (ECM) proteins (3A) and smooth muscle cells (SMCs) content and phenotype (3B) for both urinary constructs; bladder stroma cells (BSCs)-based and DF-based equivalents with immunofluorescence. Masson Trichrome (MT) and hematoxylin and eosin $(\mathrm{H} \& \mathrm{E})$ revealed that both equivalents are tri-layered with multiple layers of urothelial cells, well fused stroma and smooth muscle layer Although the different ECM proteins were detected in both equivalents but they were more expressed in BSCs=based equivalents. SMCs cells displayed different markers of SMCs maturation including those of terminal differentiation (SMA, calponin, smoothelin and desmin).

a number of diseases with varying degrees of success. ${ }^{19-23}$ To avoid the use of non-autologous tissues incorporated in these studies, a tissue-engineered construct was developed using UCs and DF, applying the principle of self-assembly. ${ }^{24,25}$ Consequently, as the lamina propria (LP) of the bladder is composed of ECM containing several types of cells, mainly fibroblasts, ${ }^{26}$ stimulating the stromal cells from LP would give rise to ECM with many characteristics similar to native urinary tissues. In one experiment, when stromal cells from LP were cocultured with UCs or SMCs, BSCs sped up the growth of both cells. ${ }^{27}$ In our results, sufficient BSCs could be easily isolated and they could maintain high proliferation capacity over passages. This makes them available for reconstructing urethral long segments and large vesical patches and makes them suitable for large-scale diagnostic experiments. ECMs were similar in both equivalents; they were thicker, better and more comparable to those of the bladder with BSCs equivalents. $^{28}$

Our results showed that both equivalents had a wellstratified urothelium. However, terminal differentiation of urothelium was obtained only with BSCs-based equivalents, as CK20 is specific for umbrella cells in normal bladder and the marker of final differentiation for superficial cells. CK14 does not stain on normal urothelium and signifies vulnerability of the bladder to future disease. ${ }^{29-31}$ It is detected in pathologic bladders, denoting squamoid phenotype change of urothelium. It is observed before morphologic squamoid differentiation and is considered a reactive response to urothelial stress or injury. This pattern of CK expression for DF-based equivalents simulates reactive urothelium with tendency towards squamous metaplasia.

As the culture conditions were the same for both types of equivalents, the difference in urothelial differentiation can be attributed to the effects of organ-specific stromal cells on urothelium development and terminal differentiation. The fibroblasts are diverse in their phenotype due to the multiple embryonic origins and the epigenetic program that reflects their location. ${ }^{32,33}$ In skin equivalents, DF of human palmoplantar skin induced the formation of an epidermis with a palmoplantar phenotype even when nonpalmoplantar epidermal cells were used. ${ }^{34}$ This indicates that site-specific differentiation of fibroblasts empowers the 


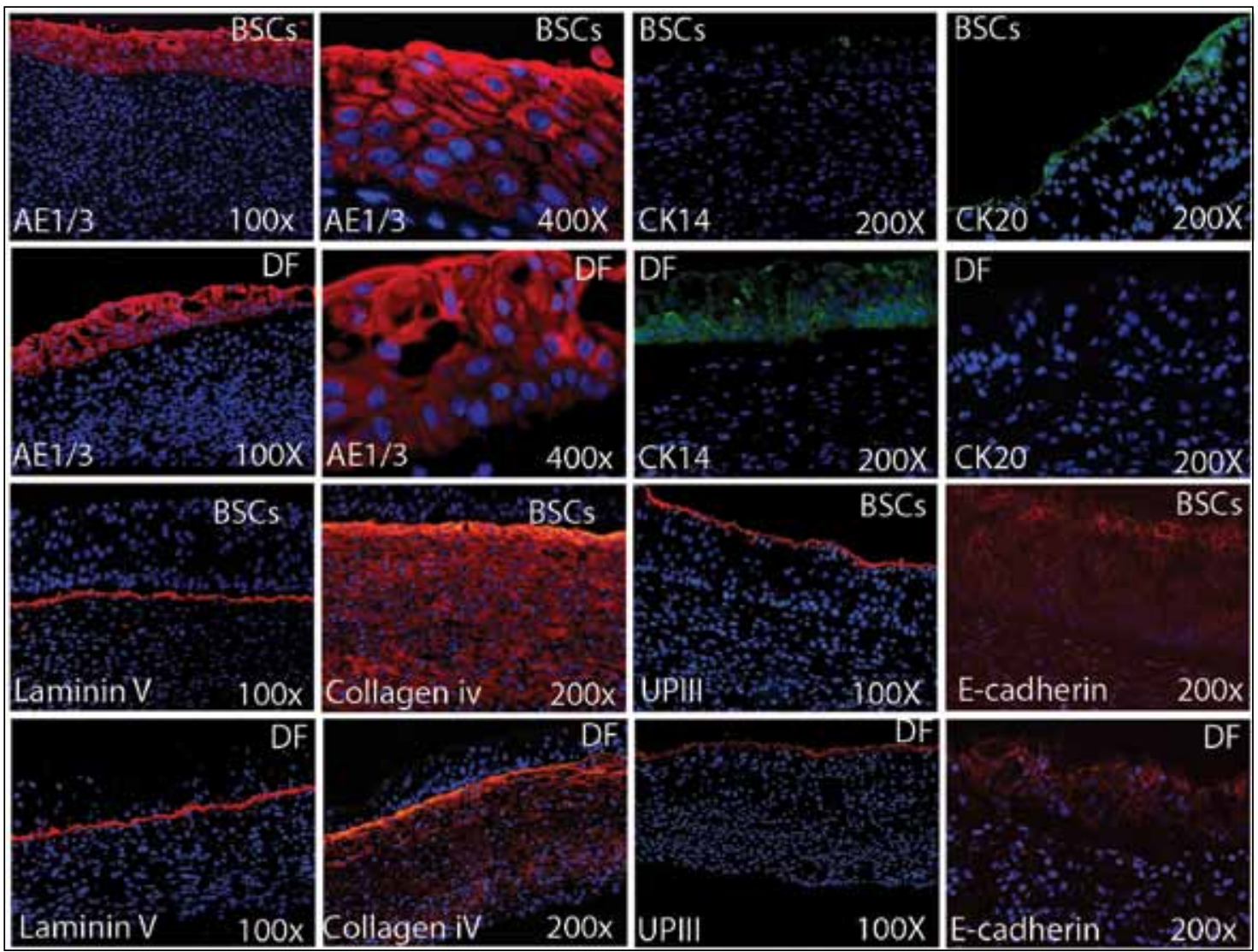

Fig. 4. Showing the expression of different epithelial and basement membrane markers among the 2 equivalents (bladder stroma cells [BSCs]-based and DF-based equivalents). Although both equivalents revealed expression of general epithelial markers (AE 1,3), uroplakin III (UPIII) and tight junctions E-cadherin, however they had different expression of cytokeratin 20 and 14. BSCsbased equivalents had terminally differentiated urothelium with evident expression of CK 20 and minimal expression of CK14, while DF-based equivalents showed the opposite. There was well-defined intact basement membrane as shown by positive staining for Laminin V and Collagen IV.

differentiation of overlying epithelial cells. Consequently, our BSCs-equivalent can act as the correct or suitable microenvironment for urothelial growth and differentiation for progenitor or stem cells.

BSCs-SMCs equivalents were more elastic than DF-SMCs with no significant difference in strength. The elasticity of BSCs-SMCs tissues is a favourable feature as these tissues should be able to distend during urine filling or expulsion, without a major increase in their intraluminal pressure. BSCsbased constructs showed mechanical characteristics similar to one-layer small intestinal submucosa, bladder acellular matrix graft (BAMG), and normal urethra. ${ }^{35}$ In engineered tissues, there is a tradeoff between improved mechanical strength and decreased extensibility, which can affect their effectiveness and how well they match the mechanical properties of native tissue.

In both types of equivalent, SMCs attached, proliferated and kept their phenotype after seeding them on collagen sheets. This denotes the applicability of adding SMCs to our self-assembled constructs. SMCs reduced inflammatory response and enhanced smooth muscle regeneration and neovascularization. ${ }^{13}$ The electron microscopy observations

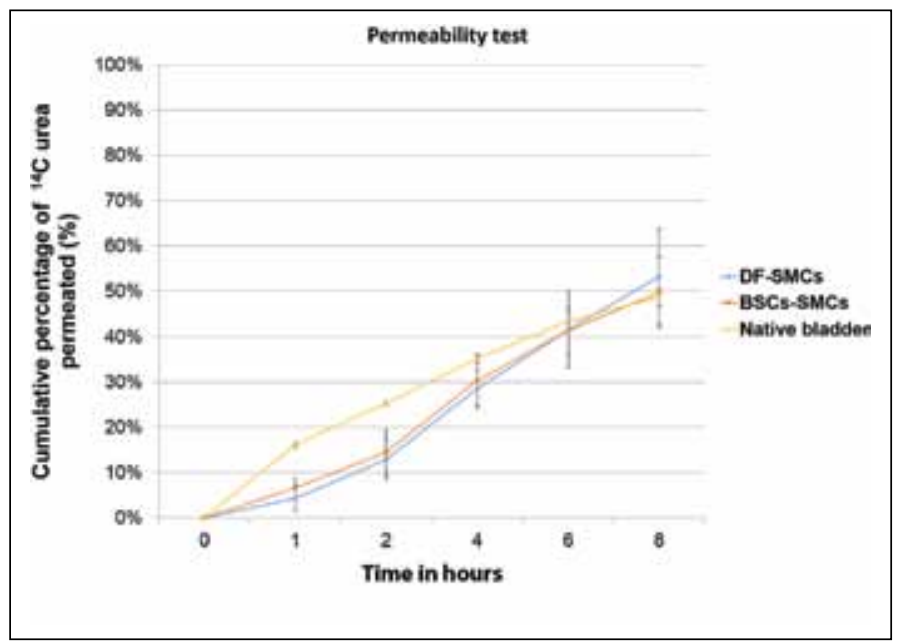

Fig. 5. Permeability test using $14 \mathrm{C}$-urea. Both equivalents were comparable to native tissues after 8 hours with no significant difference among them. 


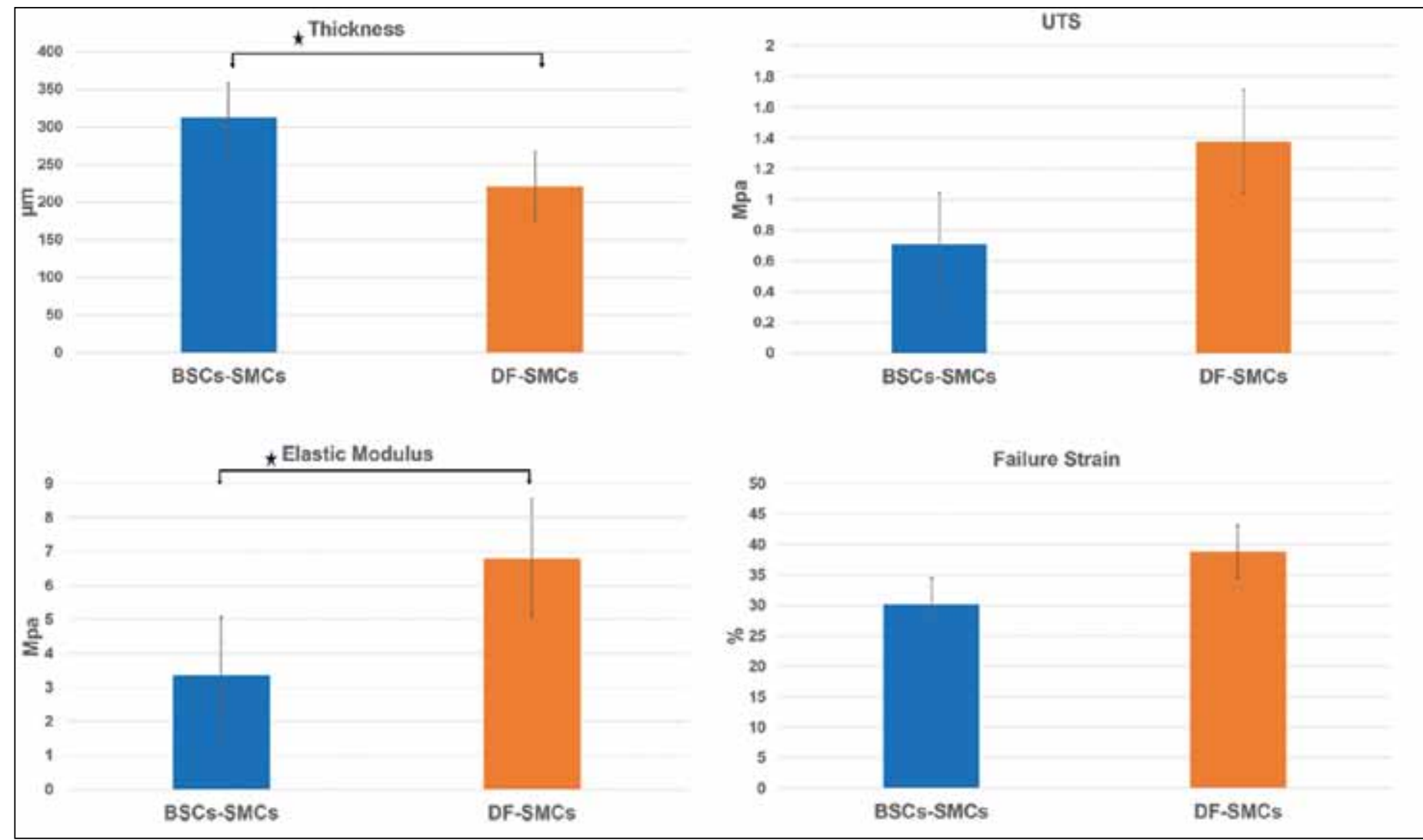

Fig. 6. Biomechanical characteristics of the urinary equivalents in regard to uniaxial tensile strength (UTS), elastic modulus and failure strain. Bladder stroma cellsbased equivalents had thicker tissue and less elastic modulus No significant difference between UTS and failure strain was detected between the 2 equivalents. Each column represents mean \pm standard error, with $p<0.05$ indicating significance: ${ }^{*} p<0.05$.

are consistent with healthy adult urothelium. ${ }^{36}$ The presence of microvilous cells enlarges the surface area and affects the bacterial attachment and fluid movement across the cell membrane. ${ }^{37}$

Although both self-assembled urinary tissues were similar in many aspects, including permeability function, BSCsSMCs had more ideal biomimetic urinary tissue because they were fully organ-specific, including stromal cells and matrix, and had thicker and elastic tissue with terminally differentiated epithelium. The limitations to our study include the long duration of equivalent formation and the lack of in vivo implantation. The replacement of urinary tract tissues is an elective procedure that does not require emergency reconstructive surgery. In vivo implantation is our next step.

\section{Conclusions}

Urinary tract specific stromal cells can give rise to ECMs using the self-assembly technique, with better physiological and mechanical characteristics than non-specific stromal cells. Our urinary equivalent is suitable as urethral graft or as bladder model for disease modelling and drug testing.
Competing interests: The authors all declare no competing financial or personal interests.

This paper has been peer-reviewed.

\section{References}

1. Hatina J, Schulz WA. Stem cells in the biology of normal urothelium and urothelial carcinoma. Neoplasma 2012;59:728-36. http://dx.doi.org/10.4149/neo_2012_089

2. Veranic $P$, Romih R, Jezernik $K$. What determines differentiation of urothelial umbrella cells? Eur J Cell Biol 2004;83:27-34. http://dx.doi.org/10.1078/0171-9335-00351

3. Veranic P, Erman A, Kerec-Kos M, et al . Rapid differentiation of superficial urothelial cells after chitosaninduced desquamation. Histochem Cell Biol 2009;131:129-39. http://dx.doi.org/10.1007/s00418008-0492-x

4. Romih R, Koprivec D, Martincic DS, et al. Restoration of the rat urothelium after cyclophosphamide treatment. Cell Biol Int 2001;25:531-7. http://dx.doi.org/10.1006/cbir.2000.0658

5. Erman A, Jezernik K, Stiblar-Martincic D, et al. Postnatal restoration of the mouse urinary bladder urothelium. Histochem Cell Biol 2001;115:309-16.

6. Kreft ME, Sterle M, Veranic $P$, et al. Urothelial injuries and the early wound healing response: Tight junctions and urothelial cytodifferentiation. Histochem Cell Biol 2005;123:529-39. http://dx.doi.org/10.1007/ s00418-005-0770-9

7. Janssen DA, Geutjes PJ, Odenthal J, et al. A new, straighfforward ex vivo organoid bladder mucosal model for predinical research. J Urol 2013;190:341-9. httrp://dx.doi.org/10.1016/i.juro.2012.12.103 

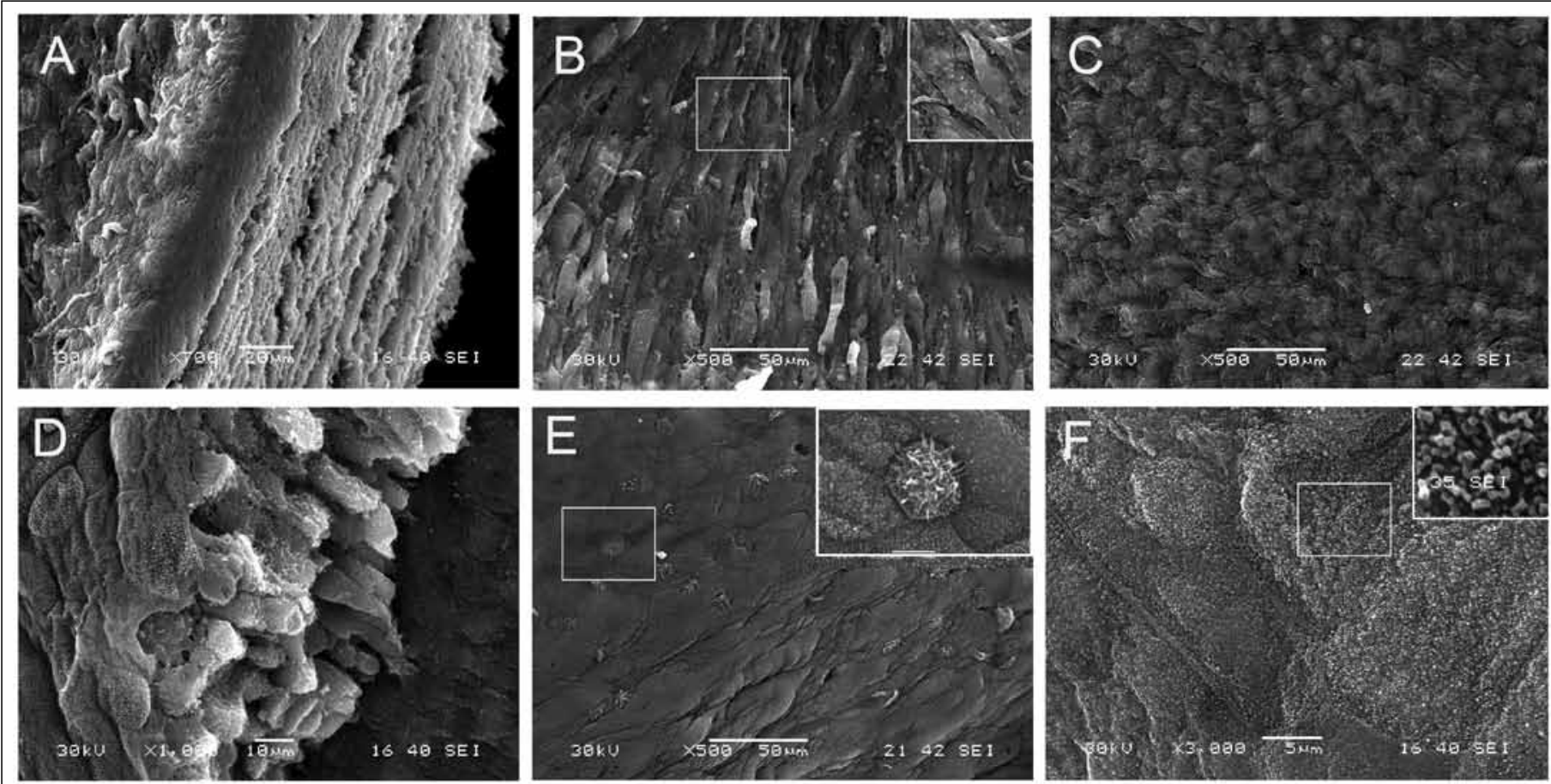

Fig. 7. Scanning electron microscopy for bladder stroma cells- smooth muscle cells (SMCs) reconstructs. A: Cut section through the whole equivalent showing the different layers and thee thick stroma. B: SMC surface with aligned smooth muscle cells. The box in the upper right corner emphasizing the spindle shaped appearance of SMCs. C: The upper surface of the stroma with tightly packed collagen. D: Cut section though the urotheium with multiple layers resting on basement membrane (BM). E: the apical surface of urothelium formed of umbrella cells with well-defined borders and scattered microvillous cells (magnified picture in the upper right corner). F: the apical membrane of umbrella cells with uroplakins particles (magnified picture in the upper right corner).

8. Zhang Y, Kropp BP, Moore P, et al. Coculture of bladder urothelial and smooth muscle cells on small intestinal submucosa: Potential applications for tissue engineering technology. J Urol 2000;164:928-34; discussion 934-5. http://dx.doi.org/10.1097/00005392-200009020-00004

9. Varley CL, Southgate J. Organotypic and $3 \mathrm{D}$ reconstructed cultures of the human bladder and urinary tract. Methods Mol Biol 2011;695:197. http://dx.doi.org/10.1007/978-1-60761-984-0_13

10. Bouhout $S$, Perron E, Gauvin R, et al. In vitro reconstruction of an autologous, watertight, and resistant vesical equivalent. Tissue Engineering 2010;16:1539-48. http://dx.doi.org/10.1089/ten. tea.2009.0473

11. Bouhout S, Gauvin R, Gibot L, et al. Bladder substitute reconstructed in a physiological pressure environment. Journal of Pediatric Urology 2011;7:276-82. http://dx.doi.org/10.1016/i.jpurol.2011.03.002

12. Cattan V, Bernard $G$, Rousseau $A$, et al. Mechanical stimuli induced urothelial differentiation in a human tissue-engineered tubular genitourinary graft. Eur Urol 2011;60:1291-8. http://dx.doi.org/10.1016/i. eururo.2011.05.051

13. Arenas da Silva LF, Micol L, Tiemessen D, et al. Is there a need for smooth muscle cell transplantation in urethral reconstruction? Tissue Eng Part A 2014;20:1542-9. http://dx.doi.org/10.1089/ten. tea. 2013.0185

14. Magnan $M$, Berthod $F$, Champigny MF, et al. In vitro reconstruction of a tissue-engineered endothelialized bladder from a single porcine biopsy. J Pediatr Urol 2006;2:261-70. http://dx.doi.org/10.1016/i. jpurol.2005.11.019

15. Auger $F A$, Lopez Valle $C A$, Guignard R, et al. Skin equivalent produced with human collagen. In Vitro Cell Dev Biol Anim 1995;31:432-9. http://dx.doi.org/10.1007/BF02634255

16. Franz TJ. Percutaneous absorption on the relevance of in vitro data. J Invest Dermatol 1975;64:190-5 http://dx.doi.org/10.1111/1523-1747.ep12533356

17. Atala A. Recent developments in tissue engineering and regenerative medicine. Curr Opin Pediat 2006;18:167-71.

18. Orabi H, Bouhout $S$, Morissette $A$, et al. Tissue engineering of urinary bladder and urethra: Advances from bench to patients. Scientific World Journal 2013;2013:154564.

19. El-Kassaby Al, AbouShwareb T, Atala A. Randomized comparative study between buccal mucosal and acellular bladder matrix grafts in complex anterior urethral strictures. J Urol 2008;179:1432-6. http:// dx.doi.org/10.1016/i.juro.2007.11.101
20. H Orabi, AS Safwat, A Shahat, et al. The use of small intestinal submucosa graft for hypospadias repair: Pilot study. Arab J Urol 2013:11:415-20. http://dx.doi.org/10.1016/i.aju.2013.09.003

21. Atala A, Bauer SB, Soker $S$, et al. Tissue-engineered autologous bladders for patients needing cystoplasty. Lancet 2006;367:1241-6. http://dx.doi.org/10.1016/S0140-6736(06)68438-9

22. Raya-Rivera A, Esquiliano DR, Yoo JJ, et al. Tissue-engineered autologous urethras for patients who need reconstruction: An observational study. Lancet 201 1;377:1 175-82. http://dx.doi.org/10.1016/ S0140-6736(10)62354-9

23. Raya-Rivera AM, Esquiliano D, Fierro-Pastrana $R$, et al. Tissue-engineered autologous vaginal organs in patients: A pilot cohort study. Lancet 2014;384:329-36. http://dx.doi.org/10.1016/S01406736(14)60542-0

24. Bouhout $S$, Perron $E$, Gauvin $R$, et al. In vitro reconstruction of an autologous, watertight, and resistant vesical equivalent. Tissue Eng Part A 2010:16:1539-48. http://dx.doi.org/10.1089/ten. tea. 2009.0473

25. Magnan $M$, Lévesque $P$, Gauvin $R$, et al. Tissue engineering of a genitourinary tubular tissue graft resistant to suturing and high internal pressures. Tissue Eng Part A 2009;15:197-202. http://dx.doi. org/10.1089/ten.tea.2007.0303

26. Aitken KJ, Bagli DJ. The bladder extracellular matrix. Part I: architecture, development and disease. Nat Rev Urol 2009:6:596-611. http://dx.doi.org/10.1038/nrurol.2009.201

27. Soler R, Fullhase C, Guimaraes-Souza N, et al. The effect of lamina propria cells on the growth of urothelial and smooth muscle cells. J Urol 2009;181:78. http://dx.doi.org/10.1016/S0022-5347(09)60225-1

28. Macarak EJ, Howard PS. The collagens and their urologic significance. Scand I Urol Nephrol Suppl 1997; 184:25-33.

29. Vaidyanathan S, McDicken IW, Ikin AJ, et al. A study of cytokeratin 20 immunostaining in urothelium of neuropathic bladder of patients with spinal cord injury. BMC Urol 2002;2:7. http://dx.doi. org/10.1186/1471-2490-2-7

30. Romih P, Vennic P, Jezernik K. Appraisal of differentiation markers in urothelial cells. Appl Immunohistochem Mol Morphol 2002;10:339-43. http://dx.doi.org/10.1097/00129039-200212000-00009

31. Vaidyanathan S, McDicken IW, Son BM, et al. Detection of early squamous metaplasia in bladder biopsies of spinal cord injury patients by immunostaining for cytokeratin 14. Spinal Cord 2003;41:432-4. http:// dx.doi.org/10.1038/si.sc.3101464 
32. Sorrell, JM, Caplan, Al. Fibroblasts. A diverse population at the center of it all. In Kwang W Jeon, editors. International Review of Cell and Molecular Biology. Burlington, MA: Academic Press; 2009:161-214.

33. Sorrell JM, Baber MA, Caplan Al. Site-matched papillary and reticular human dermal fibroblasts differ in their release of specific growth factors/cytokines and in their interaction with keratinocytes. J Cell Physiol 2004:200:134-45. http://dx.doi.org/10.1002/icp.10474

34. Yamaguchi $Y$, Itami $S$, Tarutani $M$, et al. Regulation of keratin 9 in nonpalmoplantar keratinocytes by palmoplantar fibroblasts through epithelial-mesenchymal interactions. J Invest Dermatol 1999; 1 12:4838. htrp://dx.doi.org/10.1046/j.1523-1747.1999.00544.x

35. Feng $C, X \cup Y M, F \cup Q$, et al. Evaluation of the biocompatibility and mechanical properties of naturally derived and synthetic scaffolds for urethral reconstruction. J Biomed Mater Res A 2010;94:317-25. http://dx.doi.org/10.1002/ibm.a.32729
36. Mohamed Akram Al-Motabagani. Age-related changes in the urinary bladder of the female albino rats. Int J Morphol 2005;23:309-16.

37. Birder L, Andersson KE. Urothelial signaling. Physiol Rev 2013;93:653-80. http://dx.doi.org/10.1152/ physrev.00030.2012

Correspondence: Dr. Hazem Orabi, Surgery Department, Laval University, Quebec, QC G1] 1Z4; hazem.osman.orabi@gmail.com 